\title{
Transition of Rights on Land of Palm Oil Plasma Plantation through Buying Under Hands in Cooperative Bima I Nagari Abai
}

\author{
Febri Admiral; Zainul Daulay; Ulfanora \\ Faculty of Law, Andalas University, Padang, Indonesia \\ http://dx.doi.org/10.18415/ijmmu.v6i10.893
}

\begin{abstract}
The development of the oil palm plantation industry in Indonesia in the last two decades is growing very rapidly. This plantation industry is of course very dependent on the availability of land that will be used to grow oil palm both from land controlled by the State and communal land and community agricultural land. With the need for land that is very much, of course the government must make the necessary regulations and also have to ascertain whether the regulations that have been made have been carried out by the business actors and whether the surrounding communities benefit from the existence of the oil palm plantation industry.
\end{abstract}

Koperasi BIMA I Nagari Abai, which in this paper is the object of research, is one of the realization of the oil palm plantation industry that obtained land from the Nagari Abai community and partnered with the community to give their land in a cooperative forum. Complete legal relationship with all rights and obligations that are formed because the partnership program comes from the existence of a partnership agreement between PT. Binapratama Sakatojaya as adoptive father and cooperative of BIMA I Nagari Abai as adopted son and PT. Bank Mandiri, Tbk. as a credit provider for the construction of the Koperasi BIMA I plasma plantation.

In the implementation of the partnership several problems were discovered that must be resolved immediately. Some of these problems are: legal relations that occur between PT. BPSJ with Bank Mandiri and Koperasi BIMA I related to the details of the debt and financing of the Koperasi BIMA I plasma plantation; in addition, there is also a large number of under-hand transfers of plasma plantations that are not in accordance with the rules of land law and the Articles of Association of Koperasi BIMA I Nagari Abai.

Keywords: Transition of Rights; Land; Palm Oil; Plasma Plantation 


\section{Introduction}

From the data for 2016 only, outside the citizens plantations there is an area of 179, 645 ha used by investors for oil palm plantations in West Sumatra. According to data from the Indonesian Ministry of Agriculture, the total area of oil palm plantations in Indonesia is currently around 8 million ha ; double the area in 2000 when around 4 million ha of land in Indonesia were used for oil palm plantations. This number is expected to increase to 13 million ha by 2020. It is known that the area of oil palm in 2015 was 11.3 million ha, constituting $48.6 \%$ of the total plantation area of 23.25 million ha. 4.58 million ha is community plantations, 750 thousand ha of large State plantations, and 5.97 million ha of large private plantations.

To avoid the bad things that might happen in plantation investment, then Law Number 18 Year 2004 was passed which was replaced by Law Number 39 of 2014 concerning Plantations which until now is still valid. In Law No. 39 of 2014 concerning Plantation regulates various kinds of things, one of which is regarding the obligations of a plantation company, which are listed in Article 16 paragraph (1) and (2), and Article 69 paragraph (1), only obligations contained in Article 16 paragraph (1) and (2), and Article 69 paragraph (1) does not concern the obligations between investors and oil palm farmers based on partnership agreements. So that the Republic of Indonesia Minister of Agriculture Regulation No. 98 of 2013 concerning the Guidelines for Licensing of Plantation Businesses which contains the obligations of a plantation company, besides this is also regulated regarding the relationship of plantation companies in terms of partnerships in Article 29, Article 30 and Article 31, only the relationship in the Minister of Agriculture Regulation does not specifically contain obligations between investors and oil palm farmers based on partnership agreements.

In South Solok Regency, there are currently around 4 large oil palm plantations, with 2 of them in the management of Incasi Raya Group on behalf of PT. Sumaterajaya Agrolestari located in the district Sangir Balai Janggo with a core area of more than 3,000 ha, and PT. Binapratama Sakatojaya located in Kec. Sangir Jujuhan, Sangir Balai Janggo and Sangir Batang Hari with a core area of more than 14,000 ha.

Especially for PT. Binapratama Sakatojaya itself, divided into 3 estates, namely called SS 1 in the area of Madik and Talunan (Kenagarian Abai), SS 2 in Sangir Jujuhan, and SS 3 at Bukit Gadang. For SS 1 itself, to date it has managed more than 5,000 ha of core plantations and around 800 ha of plasma plantations. This plasma plantations is managed by a legal entity in the form of a cooperative called the Bina Masyarakat I (BIMA I) Nagari Abai Kec. Sangir Batang Hari, South Solok Regency with a partnership pattern of adopted foster children. This pattern of Bapak Angkat-Anak Angkat partnership is a pattern of plasma plantation development by using bank credit facilities which are disbursed with the terms of the construction of plasma plantations which are financed / bailed out first by the adoptive father (PT. BPSJ).

At present almost $57,5 \%$ of the plasma plantations are owned by new members, most of whom are outside of Kenagarian Abai, with ownership of more than 20 ha per person / family that is not in accordance with article 5 paragraph 1 of the Deed of Establishment of Cooperative BIMA I which states who can be accepted as members of this cooperative are citizens of the Republic of Indonesia who have full ability to take legal actions and fulfill several membership requirements as follows: (1) Abai Village residents who have livelihoods as planters and oil palm plantation owners ".

That based on the Cooperative BIMA I statute itself, it is expressly stated that the members of the cooperative are residents of Abai's kenagarian. In addition, referring to articles 1 and 2 of Law No. 56 Prp. Th 1960 concerning Determination of Agricultural Land Area and 2010 population census data conducted by the Central Bureau of Statistics concerning the number and distribution of population for 
Solok Selatan Regency with a population density of 43 people / $\mathrm{km} 2$, so the dry land is not limited to rice fields with a maximum ownership of 20 ha. If it is related to Article 3 of the Government Regulation Number 224 of 1961 concerning the Implementation of Land Distribution and Granting of Damages jo. Government Regulation Number 41 of 1964 concerning Amendments and Additions to Government Regulation No. 224 of 1961 About the Implementation of Land Distribution and Giving Compensation which prohibits land ownership in absentee, then in reality there are many things in the practice that are contrary to the applicable law.

\section{Formulation of the problem}

Based on the background of the problem, a research problem can be formulated, namely about the transfer of ownership rights to oil palm plasma land through buying and selling under the hands of Cooperative BIMA I Nagari Abai?

\section{Research methods}

Because this study examines the transfer of ownership rights to oil palm plasma land through buying and selling under the hands of Cooperative BIMA I Nagari Abai in the category of empirical legal research (sociology). And is descriptive analytical,

\section{Results and Discussion}

The plasma land ownership of oil palm plantations managed by Cooperative BIMA I until the first quarter of 2019 has more than 57,5\% owned by new owners due to the buying and selling process that occurred. Many factors that cause the amount of plasma land to be sold by the first plasma participants, such as economic factors, are skeptical about the relocation of plasma development, the transfer of plasma participants to other regions, and so on. This alone certainly raises some contradictions with the relevant rules, as found in the study that there were land purchased by buyers who resided outside Kec. Sangir Batang Hari, and some even resided outside the province of West Sumatra and had more than 20 ha.

A. Prohibition of ownership of agricultural land with an area exceeding the permitted and in absentee.

Based on Articles 1 and 2 of Law No. 56 Prp. Th 1960 concerning Determination of Agricultural Land Size and 2010 population census data conducted by the Central Bureau of Statistics concerning the number and distribution of population for Solok Selatan Regency with a population density of 43 people / $\mathrm{km} 2$, so the dry land is not limited to rice fields with a maximum ownership of 20 ha.

The absentee prohibition of land ownership is based on the law in Article 10 (1) of the UUPA, as follows:

"Every person and legal entity that has a right to agricultural land on the principle is obliged to work on it or actively cultivate it, by preventing ways of extortion".

To carry out the mandate of the UUPA, then based on Article 3 paragraph (1) PP Number 224 Year 1961 jo. PP No. 41 of 1964 determines the following:

"Farm owners who live outside the subdistrict where the land is located, within a period of 6 months must transfer their land rights to other people in the district where the land is located or move to the sub-district where the land is located". 
Furthermore, Article 3d PP No. 224 of 1961 jo. PP Number 41 of 1964 determines:

"It is forbidden to carry out all forms of transferring new rights to agricultural land resulting in the landowners concerned has a parcel outside the sub-district where he resides".

From the provisions above, it can be seen that the provisions of absentee include:

1. Agricultural lands must be actively worked on or cultivated;

2. Owners of agricultural land must live in the district where the land is located;

3. Farmers who live outside the subdistrict where the land is located, are obliged to transfer their rights to the land or move to the sub-district where the land is located;

4. It is prohibited to move or transfer the rights to agricultural land to a person or legal entity residing or domiciled outside the sub-district where the land is located;

5. The prohibition on absentee land ownership only concerns agricultural land.

\section{B. BIMA I Cooperative Membership}

Whereas in the Deed of Establishment of Cooperative BIMA I Number: 37 / BH / KDK.3.4 / IV / 1999 dated 13 April 1999, Regarding Membership in article 5 reads:

"That can be accepted as members of this cooperative are citizens of the Republic of Indonesia who have the full ability to take legal action and fulfill several membership requirements as follows:

(1) Abai villagers who have livelihoods as planters and owners of oil palm plantations.

Next in Article 7 reads:

"Cooperative membership is attached to each member and cannot be transferred / transferred to other people".

Whereas in the Cooperative BIMA I, related to the matters outlined above, the reality that occurred in connection with the large number of land purchases of plasma estates generally occurred due to economic factors from the initial landowners, so they chose the prakis steps to sell their plasma garden land plus no knowledge that this is not permitted in law. The Management of Cooperative BIMA I always provided input and views and explanations so as not to sell the land. The Cooperative Management through the Cooperative Head (Buyung R.) always explains several things, namely:

1. the condition of the growing plasma garden for our offspring later,

2. cooperative debt that has not been paid off in the bank so that the certificate cannot return the name because it is still in the hands of the creditor,

3. cooperative membership that automatically switches

3. Garden land is controlled by other people who are not residents of Nagari Abai (even outside the Province of West Sumatra) 
Even the local government has appealed not to sell the land, but for various reasons the owner continues to sell the land, even Mr. Buyung R. as Head of the Cooperative BIMA I often gets innuendos and unpleasant words from both the seller and the buyer. so as not to be blamed later, in the plasma plantation land purchase agreement under the management of the Cooperative BIMA I, the Cooperative BIMA I Board also requires that every sale under the hand be known to Wali Nagari Abai and KAN Chair Nagari Abai.

The existence of several violations of the laws and regulations and the Cooperative BIMA I Articles of Association can legally lead to the null and void of sale and purchase agreements that have taken place under the law aimed at transferring ownership of oil palm plasma plantations (agricultural land), including Cooperative membership BIMA I. However, until now because the certificate of ownership of all members of Cooperative BIMA I, including those who have sold whose names are still the owners of the initial certificates, have not yet been tested the effectiveness of legislation and the BIMA I Cooperative's Articles of Association are up to date.

\section{Conclussion}

Based on the results of the discussion of the problems in this thesis, conclusions can be made as follows:

Whereas the legal consequences of the transfer of land rights to oil palm plasma plantations at Cooperative BIMA I were under the hands, including those purchased by people outside the Kec. Sangir Batang Hari, Solok Selatan regency, which automatically replaces the position of the old owner as a member of Cooperative BIMA I, has the potential to be null and void. The transfer of ownership rights to the material through a sale and purchase agreement is carried out in which the provisions of the law require that the acquisition of property rights based on submission must meet the conditions set forth in article 1320 of the Civil Code. As for the transfer of oil palm plasma land rights to the Cooperative BIMA I under the hands that occurred should not be in accordance with the rules of questioning land ownership in absentee and also violating the Cooperative BIMA I Articles of Association which stated that the members of the Cooperative were residents of Abai Village (now Nagari Abai).

\section{References}

Adrian Sutedi, Peralihan Hak Atas Tanah dan Pendadftarannya, Sinar Grafika,

Aminuddin Sal,, Hukum Agraria, AS Publising, Jakarta. 2010.

Dinas Perkebunan Provinsi Sumatera Barat, Data dan Statistik Perkebunan, 2017.

Effendi Perangin, Hukum Agraria di Indonesia, CV. Rajawali, Jakarta, 1986.

J. Andy Hartanto, Hukum Pertanahan, LaksBang Justitia, Surabaya, 2014.

Kartini Muljadi dan Gunawan W., Hak-Hak Atas Tanah Seri Hukum Harta Kekayaan, Prenada Media, Jakarta, 2004.

Kitab Undang-Undang Hukum Perdata.

Kurnia Warman, Hukum Agraria Dalam Masyarakat Majemuk, HUMA, Jakarta, 2010. 
Mentan Canangkan Satu Juta Integrasi Jagung - Sawit Mendukung Program Replanting,http://www.pertanian.go.id/ap_posts/detil/579/2016/05/27/18/06/3 1/Mentan\%20Canangkan\%20Satu\%20Juta\%20Integrasi\%20Jagung\%20\%20 Sawit\%20Mendukung\%20Program\%20Replanting, diakses 24 Oktober 2018.

Minyak kelapa sawit, http://www.indonesia-investments.com/id/bisnis/komoditas/- minyaksawit/item166, diakses 24 Oktober 2018.

Mohammad Jafar Hafsah, Kemitraan Usaha, Pustaka Sinar Harapan, Jakarta, 2000.

Muctar Wahid,Memaknai Kepastian Hukum Hak Milik Atas Tanah, Republika, Jakarta, 2008.

Mukti Fajar dan Yulianto Achmad, Dualisme Penelitian Hukum Normatif dan Empiris, Pustaka Pelajar, Yogyakarta, 2010.

Peraturan Menteri Pertanian Republik Indonesia Nomor 98 Tahun 2013 tentang Pedoman Perizinan Usaha Perkebunan.

Peraturan Menteri Pertanian Republik IndonesiaNomor: 29/Permentan/Kb.410/5/2016TentangPerubahan Atas Peraturan Menteri PertanianNomor 8/Permentan/Ot.140/9/2013TentangPedoman Perizinan Usaha Perkebunan.

Peraturan MenteriAgraria Dan Tata Ruang/Kepala Badan Pertanahan Nasional Nomor 7 Tahun 2017TentangPengaturan Dan Tata Cara Penetapan Hak Guna Usaha.

Peraturan Pemerintah Nomor 224 tahun 1961 tentang Pelaksanaan Pembagian Tanah DanPemberian Ganti Kerugian.

Peraturan Pemerintah Nomor 41 tahun 1964 tentang Perubahan DanTambahan Peraturan Pemerintah No. 224 Tahun 1961TentangPelaksanaan Pembagian Tanah Dan Pemberian GantiKerugian.

PeraturanPemerintah Nomor 24 Tahun 1997 tentang Pendaftaran Tanah.

Peraturan Pemerintah Nomor 17 tahun 2013 tentang Pelaksanaan Undang-Undang Nomor 20 Tahun 2008 tentang Usaha Mikro, Kecil, dan Menengah.

Robiatul Adawiyah, Keabsahan Jual Beli Tanah dengan Alat Bukti Kwitansi,

https://www.academia.edu/33922437/Keabsahan_Jual_Beli_Tanah_dengan_Alat_Bukti_Kwitansi, diunduh pada Minggu 30Maret 2019.

Sumadi Suryabrata, Metodologi Penelitian, Rajawali Pers, Jakarta, 1987.

Undang-Undang Nomor 5 Tahun 1960 tentang Pokok Pokok Agraria.

Undang-Undang Nomor 56 Prp. Tahun 1960 tentang Penetapan Luas Tanah Pertanian.

Undang-Undang Nomor 25 Tahun 1992 tentang Perkoperasian.

Undang-Undang Nomor 25 Tahun 2007 tentang Penanaman Modal. 
Undang-Undang Nomor 20 tahun 2008 tentang Usaha Mikro, Kecil, dan Menengah.

Website BPS Kab. Solok Selatan; https://sp2010.bps.go.id/index.php/site?id=1310000000\&wilayah=SolokSelatan(terakhir kali dikunjung pada 02 April 2019).

Website GAPKI; https://gapki.id/news/3929/perubahan-berangsur-kemitraan-yang- menghasilkan-revolusisawit (terakhir kali dikunjung pada 02 April 2019).

\section{Copyrights}

Copyright for this article is retained by the author(s), with first publication rights granted to the journal.

This is an open-access article distributed under the terms and conditions of the Creative Commons Attribution license (http://creativecommons.org/licenses/by/4.0/). 